\title{
Lived Historiography: National History as a Script to the Past
}

\author{
Pertti Haapala \\ LIVING TEXT
}

Stories are not lived but told. Life has no beginnings, middles, or ends; there are meetings, but the start of an affair belongs to the story we tell ourselves later, and there are partings, but final partings only in the story. There are hopes, plans, battles and ideas, but only in retrospective stories are hopes unfulfilled, plans miscarried, battles decisive, and ideas seminal [...] We do not dream or remember in narrative, I think, but tell stories which weave together the separate images of recollection.

The citation above from Louis Mink is known as one of the founding ideas of historical narratology. ${ }^{1}$ It fits well with the basic idea of this chapter, which studies how the past is experienced as a narrative and how

${ }^{1}$ Louis O. Mink, "History and Fiction as Modes of Comprehension," New Literary History 1:3 (1970), 557-8.

P. Haapala $(\bowtie)$

Tampere University, Tampere, Finland

e-mail: pertti.haapala@tuni.fi

(C) The Author(s) 2021

V. Kivimäki et al. (eds.), Lived Nation as the History of Experiences and Emotions in Finland, 1800-2000, Palgrave Studies in the History of Experience, https://doi.org/10.1007/978-3-030-69882-9_2 
historical narratives determine experiences. In basic terms, historical narrative is one's personal understanding of the past derived from one's own life experiences and especially from their intertwinement with historical moments. These, in turn, are usually shared experiences, which are lived and defined both individually and collectively. ${ }^{2}$ The combination of the personal and the collective is how stories of the past spring to life and become history in people's minds. Without discussing the question of historical truth here, the stories represent the "real" past to people who learn to see themselves in a given historical context-whatever its "objective" factuality. Consequently, history becomes one dimension in people's present lives, and it may have a strong impact on how they position themselves, how they value and judge past events, how they interpret the present, and what they expect from the future. ${ }^{3}$

Historical imagination is materialized in written summaries of the past, typically in the form of historiography. The stories tell about the past, but they also work as culturally determined collective scripts for reading the present-by giving the contemporary experience a historically reasoned meaning. In other words, the (imagined) past defines the (actual) present-and vice versa. ${ }^{4}$ If that is indeed the case, it is relevant to ask where these scripts come from. This chapter focuses on one of their origins, history writing, academic and non-academic. The question is not only about how people adopted some key conceptions such as the nation from historiography, but how they "lived their past" conceptually and how the narratives of the past extended to their personal lives both collectively and diachronically. "Narrative qualities are transferred from art to life," Louis Mink wrote, and concluded: "it is from history and fiction that we learn how to tell and understand complex stories." 5 The formation of modern

\footnotetext{
${ }^{2}$ Frank Ankersmit, Meaning, Truth, and Reference in Historical Representation (Ithaca: Cornell University Press, 2012), offers a distinction between different categories of historical experience, "objective," "individualist," and "collectivist" and poses the question: which comes first, language or experience? (Chapters 9 and 10 and p. 176).

${ }^{3}$ On this aspect of "historical thinking" see Reinhard Koselleck, Futures Past: On the Semantics of Historical Time (New York: Columbia University Press, 2004), and Jörn Rüsen, Evidence and Meaning: A Theory of Historical Studies (New York: Berghahn Books, 2017).

${ }^{4}$ About the concept and idea of script, see David Herman, "Scripts, Sequences, and Stories: Elements of a Postclassical Narratology," Modern Language Association 112:5 (1997), 1046-59.

${ }^{5}$ Mink (1970), 558. A more disciplined analysis of conceptions and experiences can be found in Margrit Pernau \& Imke Rajamani, "Emotional Translations: Conceptual History Beyond Language," History and Theory 55:1 (2016), 46-65.
} 
societies and nation states represent the kind of complex stories which require historical narratives for their explanation.

It has been widely analyzed as to how a specific model of historiography, national history, became a new paradigm and master narrative in the academic and public discourses of the nineteenth century and how it played a major role in politics up until the twenty-first century. ${ }^{6}$ What makes the role of national history interesting is that the nineteenth and twentieth centuries were an era of modernization, globalization, and a new kind of "scientific" historiography, one which aimed at eliminating all metaphysical and ideological explanations from history writing. One could therefore expect that national(istic) historiography was born into a wrong world. But, as is also well-known, the nation-states were formed at the same time in the wake of modernization-and national history served as a political justification of that process. National identity contained a deep historical dimension, because it was constructed to justify nationality through "shared" history and tradition. The nation's past, present, and future were logically contingent and tied to each other as narrative structures. In the big picture, the story worked in all modern societies: historical consciousness grew among people of all social strata, national identities emerged, and people bound their personal lives and involvement to the nation. ${ }^{7}$

It is impossible, of course, to know exactly how people have lived their past, and it is irrelevant to try to capture all their "authentic" experiences in the sense of direct, immediate impressions. But there are ways to make the research into historical experiences possible and relevant. First of all, people have expressed and presented their thoughts and feelings, and these experiences can be used to trace collective patterns of thinking. It is also credible to expect that those views which are widely repeated and referred represent socially shared and widely meaningful collective experiences. In addition, we know that history as a set of ideas is basically what has been taught and believed to be "true" history, that is, the past becomes

\footnotetext{
${ }^{6}$ For the European and Nordic contexts see Writing the Nation Series (Palgrave, 2008-2015), especially Stefan Berger \& Chris Lorenz, eds, The Contested Nation: Ethnicity, Class, Religion and Gender in National Histories (Basingstoke: Palgrave Macmillan, 2008). On the concept of master narrative, see Krijn Thijs, "The Metaphor of the Master: 'Narrative Hierarchy' in National History Cultures of Europe," in Berger \& Lorenz (2008), 60-74.

${ }^{7}$ Carsten Humlebæk, "National Identities: Temporality and Narration," Genealogy 2:36 (2018), 1-18; Maarten van Ginderachter, Andreas Stynen \& Xosé M. Núnez Seixas, eds, Emotions and Everyday Nationalism in Modern European History (London: Routledge, 2020).
} 
history via a learning process within educational institutions (academia and schools) and in the public discourse (media and politics).

It is hypothesized here that academic historiography produced much of the collective historical experience of the nation, in this case that of Finland. Academic writers invented the idea of national history, and their representations of the national past were then actively distributed. In traditional historiography, written by academics themselves, it has been taken for granted that their ideas of history penetrated the whole of society and even determined the fate of the nation. That is questionable, of course, but it is worth asking how academic historiography contributed to patterns of thinking among the wider circles of Finns who were experiencing their history, either lived or told.

I demonstrate here below-through selected examples-the role of (Finnish) historiography in "organizing" the experience of a nation, its key moments, and collective memory. The outcome, the more or less shared understanding of the past and its meanings, may be called the autobiography of a nation. It is a narrative, but it is more than that: it is an autobiography of a society which produces its own social order and history. ${ }^{8}$ In that sense, history writing has a social history, written by someone, and to be shared as the common experience of a particular community. There are, undoubtedly, many simultaneous conceptions of the past, but for some reason one narrative often becomes dominant and more paradigmatic for the given nation than others. At least a partial explanation for that is that the narrative serves readily as a script, a kind of mindmap, to follow or as a code that gives collective meanings to individual experiences. ${ }^{9}$ How that process works in a living society is not a question of scientific argumentation; rather, its relevance depends on how it justifies the present societal relations and political practices and connects them to history. That dynamics may be called lived historiography. It is a story of the past, but it is also a story of those who wrote it and those who lived it, a story which was told and lived -in that order.

\footnotetext{
${ }^{8}$ About the idea of society's self-production, see Alain Touraine, The Voice and the Eye: An Analysis of Social Movements (Cambridge: Cambridge University Press, 1981).

${ }^{9}$ This model is typical in cultural anthropology but usually absent in historiographical studies. See William H. Sewell Jr., Logics of History: Social Theory and Social Transformation (Chicago: Chicago University Press, 2004); Katie Barclay, "New Materialism and the New History of Emotions," Emotions: History, Culture, Society 1:1 (2017), 161-83.
} 


\section{InVEnTing the Nation ANd ITs Story}

The history of Finland was invented by a group of nationally minded intellectuals during the first half of the nineteenth century following the ideas of contemporary European philosophers and historians, especially those of the German romantic tradition. ${ }^{10}$ For the Finnish case, the process and its timing were closely linked to the consequences of the Napoleonic Wars, when Finland was annexed to the Russian Empire in 1809 after being an integral part of the Kingdom of Sweden since the twelfth century. Separation from Sweden and distance from Russian traditions (in language, religion, and legislation) compelled the Finnish elites to rethink their position, well expressed in the famous phrase: "We are no longer Swedes, we will not become Russians, let us be Finns." Actually, the statement was not made in Finnish, and it was not at the time an expression of nationalism but a statement of the fact that a new political unit was (in the process of being) born in between Sweden and Russia. ${ }^{11}$ The Russian Emperor himself declared that Finland "was placed in the rank of nations"- a phrase which was later given different meanings. ${ }^{12}$ In any case, the new Grand Duchy of Finland was now ruled by the local elite who compromised with the Russians to safeguard their own leading position-but not at the expense of the peasants as the German elite did in the Baltic provinces. ${ }^{13}$ The ruling Finns adopted a double identity: they were Swedish-speaking Finns but loyal to the Russian Empire. Even a moderate

\footnotetext{
${ }^{10}$ Stefan Berger \& Chris Lorenz, eds, Nationalizing the Past: Historians as Nation Builders in Modern Europe (Basingstoke: Palgrave Macmillan, 2010); Miroslav Hroch, European Nations: Explaining Their Formation (London: Verso, 2015); Robert Schweitzer, ed., Zweihundert Jahre deutsche Finnlandbegeisterung: Zur Entwicklung des deutschen Finnlandbildesseit August Thiemes "Finnland"-Poem von 1808 (Berlin: BerlinerWissenschaftsVerlag, 2010). On the eighteenth-century proto-nationalism in Finland, see Juha Manninen, Valistus ja kansallinen identiteetti: Aatehistoriallinen tutkimus 1700-luvun Pohjolasta (Helsinki: SKS, 2000).

${ }^{11}$ Later the phrase was employed by-anti-Swedish and anti-Russian-nationalism. About this see Jani Marjanen, “Svensk äro vi icke mera': Om ett utryckts historia," in Köpa salt I Cádiz och andra berättälser, ed. by Henrika Tandefelt, Julia Dahlberg, Aapo Roselius \& Oula Silvennoinen (Helsinki: Siltala, 2020), 163-84.

${ }^{12}$ The original text was "la Finlande est placée au rang des nations" and was meant to say that Russia liberated the Finns. Later the text was translated into Finnish a bit differently: Finland was elevated to being a nation among other nations, that is Finland was made equal to the states of Sweden and Russia.

${ }^{13}$ Edward Thaden, Russia's Western Borderlands, 1710-1870 (Princeton: Princeton University Press, 1984).
} 
vision of the possibility for a small sovereign Finnish state did not appear realistic to anyone at the time. Despite its growing economic and political connections to Russia, Finland remained culturally linked to Sweden and Germany. ${ }^{14}$

The first history of Finland was published in 1809 by German historian Friedrich Rühs, who compiled parts of his earlier history of Sweden under the title Finnland und seine Bewohner. ${ }^{15}$ The book was translated into Swedish in Stockholm and used by students in Finland but gained no wider popularity. In 1832, author and politician A. I. Arwidsson published a supplemented version of Rühs' book in Swedish emphasizing the cultural autonomy of Finland. Arwidsson himself had been expelled from Finland to Sweden for his anti-Russian opinions ten years earlier. ${ }^{16}$ When the Kalevala, the famous collection of epic folk poetry, was first published in 1835 , it was presented and read as the true history of the Finnish people and as evidence of the original Finnish culture, a model familiar from several "nations without a state." 17 Despite some enthusiasm among intellectuals, the Kalevala's first edition sold only a few hundred copies because educated people did not read Finnish and the Finnish-speaking peasants could not read or were not interested. Still, in 1843, a young man named Zacharias Topelius posed to his fellow students the critical question "Do the Finnish people have a history?" - to which he gave a negative answer, because the Finns had no national feeling or identity and the necessary elements of a nation had not been developed during foreign rule. ${ }^{18}$ The discussion's conclusion, however, was that the history of Finland

${ }^{14}$ Max Engman, Pitkät jäähyväiset: Suomi Ruotsin ja Venäjän välissä vuoden 1809 jälkeen (Helsinki: WSOY, 2010); Jan Hecker-Stampehl \& al, eds, 1809 und die Folgen: Finnland zwischen Schweden, Russland und Deutschland (Berlin: Berliner Wissenschafts-Verlag, 2011). New Russian connections-among European-are emphasized in Matti Klinge, A History both Finnish and European: History and the Culture of Historical Writing in Finland during the Imperial Period (Helsinki: The Finnish Society of Sciences and Letters, 2012).

${ }^{15}$ Friedrich Rühs, Finnland und seine Bewohner (Leipzig: Georg Göschen, 1809).

${ }^{16}$ Adolf Ivar Arwidsson, Lärobok $i$ Finlands historia och geografi för gymnasier och skolor (Turku: S. S. Arwidsson, 1832). Arwidsson never returned to Finland but was celebrated as a national hero after his death in 1858 .

${ }^{17}$ Similar cases were Norway under Sweden, Iceland under Denmark, the Baltic provinces under Russian and German influence and the many nations under the Habsburg Empire.

${ }^{18}$ Topelius' speech ("Äger det finska folket en historia") was published in 1845 in Joukabainen 2 (1845), 189-217. In Sweden it was dismissed with the claim that "Finland had a history, that of Sweden." Paul Nyberg, Z. Topelius: Elämäkerrallinen kuvaus (Porvoo: WSOY 1950), 168-9. 
needed to be written and that this should be the task of the nationally enlightened youth who called themselves Fennomans. Their ideological leader was J. V. Snellman, then a radical student of Hegel, and later known as the "national philosopher" and founding father of Finnish statehood. ${ }^{19}$

At this point, the history of Finland was a mere idea current among intellectuals inspired by Herder, Hegel, and Finnish mythology. The Fennomans' connection to the "real people" has later been described as a romance in which young (male) intellectuals "found the simple beauty of the people, their melodious language and saw the rustic Finnish people as a Cinderella, a dear Princess in her rags." ${ }^{20}$ The metaphor is fairly correct in emphasizing the idealistic and emotional dimension of the Fennomans' historical imagination. The peasant folk they "admired from afar" were real, but their history, experiences, and sufferings were idealized and nationalized, most famously through the national romantic poetry of Johan Ludvig Runeberg after the 1830s. As Runeberg was originally read only by the small Swedish-speaking, educated classes, we may continue the romance metaphor: the bride and the groom had seen each other but they were not acquaintances. ${ }^{21}$ There was as yet no joint story of the nation: common folk's conceptions of the earlier times were based on the Bible and the Lutheran hymn-book's appendix of historical dates. ${ }^{22}$

It was as late as 1869 when the first History of Finland was published in Finnish by professor Yrjö Koskinen. ${ }^{23}$ His story started by describing how Finns as a single population had moved to Finland from the east. The remote eastern origins of the Finns separated them from the Swedes and the Slavs. ${ }^{24}$ During the Swedish period, Finns became Christians, fought

${ }^{19}$ Marja Jalava, J.V. Snellman: Mies ja suurmies (Helsinki: Tammi, 2006) is a concise history of the "great man" whose collected works can be found at http://snellman.kootutteokset.fi/en, accessed 24 August 2020.

${ }^{20}$ Gunnar Suolahti, Nuori Yrjö Koskinen (Porvoo: WSOY, 1933), 16.

${ }^{21}$ A detailed study on Runeberg's political thinking is Matti Klinge, Poliittinen Runeberg (Helsinki: WSOY, 2004).

${ }^{22}$ Ajan-Tieto [Chronicle] covered the time from the Creation until the present. An 1859 version is available at http://koraali.fi/1701/ajantieto/ajantietol5.html, accessed 24 August 2020.

${ }^{23}$ Yrjö Koskinen, Oppikirja Suomen kansan historiassa (Helsinki: SKS, 1869). Several enlarged editions were published in the coming decades. The author, Georg Forsman, used a political pseudonym. Yrjö Koskinen was his name translated in Finnish.

${ }^{24}$ The migration theory was supported by linguistics and archeologists well into the twentieth century, see Derek Fewster, Visions of Past Glory: Nationalism and the Construction of Early Finnish History (Helsinki: Studia Fennica Historica 11, 2006). Today's knowledge is 
for the Reformation and defended Sweden against Russia. But the toll was so heavy that it was only God's wisdom to separate Finland from Sweden and to offer better conditions for a national awakening under the Russian rule. That was the purpose of history for Koskinen. From today's perspective the professor's argument is not very strong but for him and his fellowpatriots, things were self-evident: "The people of Finland want to have a history, ergo: they have a history [...] The will itself proves that the specific nation exists." 25

Koskinen's way of writing history was exactly what was needed for locating Finns within the grand narratives of Christianity and the empires. The story explained the current situation and justified the emerging political claims for national statehood (see below). Most importantly, Koskinen proved that Finnish people had a history through belonging to a nation. It is difficult to know how deeply the Finns adopted this idea, but there is ample evidence of its growing popularity from the 1860s on. The key concepts, the nation and its history, were repeated in academia, in political discourse, in newspapers, in schoolbooks, in fiction, and in the performing arts. Historical fiction was the most powerful and best-known form of representing "national heritage" of the time. ${ }^{26}$ Runeberg was declared to be the "national poet," especially due to his lyrical history of the "War of Finland" in 1808-09, when Russia conquered Finnish territory from Sweden. He valued the Swedish tradition, but he also made Finns the idealized heroes of the lost war and wrote about our nation, a nation which deserved its existence. His poem "Our Land" from 1846, at the time a manifestation of loyal patriotism, became later the national anthem of Finland. ${ }^{27}$

Zacharias Topelius became the first professor of Finnish history in 1854. Displaying the importance of narrative skills in writing history, he

that the population of Finland has a variety of origins and there has never been any "original" Finnish people.

${ }^{25}$ Yrjö Koskinen, “Onko Suomen kansalla historiaa?” Historiallinen Arkisto V (1876), 9. Italics by Koskinen.

${ }^{26}$ Linda Kaljundi, Eneken Laanes \& Ilona Pikkanen, eds, Novels, Histories, Novel Nations: Historical Fiction and Cultural Memory in Finland and Estonia (Helsinki: SKS, 2015); Marja Jalava, Tiina Kinnunen \& Irma Sulkunen, eds, Kirjoitettu kansakunta: Sukupuoli, uskonto ja kansallinen historia 1900-luvun alkupuolen suomalaisessa tietokirjallisuudessa (Helsinki: SKS, 2013).

${ }^{27}$ Johan Wrede, Se kansa meidän kansa on: Runeberg, vänrikki ja kansakunta (Helsinki: Gummerus, 1988); Klinge (2004). 
made his career mainly as a novelist and playwright. ${ }^{28}$ In his novel series Surgeon's Stories (1853-67), Topelius presented the joint history of Sweden and Finland as the parallel stories of two families, a noble one and a peasant one. ${ }^{29}$ These families represented two peoples whose fate was intertwined-and when it came time to separate, the Finns were prepared to follow their own path. In the first Finnish opera (1852), written by Topelius, the Finnish country people bid a grateful farewell to their Swedish king. ${ }^{30}$ An increasingly independent role between Sweden and Russia was an appealing identity, and it was easy to adopt emotionally; the sufferings of earlier wars were forgotten in giving them a positive meaning as the cradle of the Finnish nation. The Swedish cultural tradition emphasizing Lutheranism and the rule of law was transformed into a Finnish tradition, distinct from the Russian one.

The most compelling description of Finnish history was Topelius' reader for young people, The Book of Our Land, written in Swedish but published immediately in Finnish, too, in 1875. The book's opening lines are: "This book tells about Finland. It tells about the fatherland. What is Finland? It is a country among other countries. What is the fatherland? It is our great home." There follow chapters on Finland's nature and its people, and on their long history. The book ends in the words of a child: "Now I know it [my fatherland]." 31 The work followed the European model of adopting a child's perspective, an intentional metaphor for the awakening of the people as a nation both individually and collectively. ${ }^{32}$

${ }^{28}$ Matti Klinge, Idylli ja ubka: Topeliuksen aatteita ja politiikkaa (Helsinki: WSOY, 1998) is a detailed account on Topelius' ideas and societal thinking concerning especially his idea of Finland.

${ }^{29}$ Zacharias Topelius, The Surgeon's Stories: A Series of Swedish Historical Romances, in six cycles (Chicago: Jansen, McClurg \& Co, 1882-1884). The original texts were published in Swedish and in Finnish 1878-82, and since then in several new editions and translations.

${ }^{30}$ Mari Hatavara, "Composing Finnish National History: Zacharias Topelius' The Surgeon's Stories," in Kaljundi, Laanes \& Pikkanen (2015), 79-97; Petra Lehtoruusu, "Adapting history: Topelius' The Surgeon's Stories and cultural memory in Finland and Sweden," Ennen ja nyt 4/2019, https://www.ennenjanyt.net/2019/12/adapting-historytopelius-the-surgeons-stories-and-cultural-memory-in-finland-and-sweden, accessed 24 August 2020.

${ }^{31}$ Z. Topelius, Maamme kirja (Helsinki: WSOY 1985 [1875]), 15, 562.

${ }^{32}$ Patrick Cabanel, Le tour de la nation par des enfants: Romans scolaires et espaces nationaux, $x i x^{\mathrm{c}}-x x^{\mathrm{e}}$ siècles (Paris: Belin, 2007). A similar work in Sweden was Selma Lagerlöf's Nils Holgerssons underbara resa genom Sverige (1906-1907). She published an admiring biography of Topelius in 1920 and witnessed for Topelius' importance for Swedish children, too. 
And history promised a bright future, too. Topelius explained how Finns could become a model for less fortunate peoples and for the whole of humankind. ${ }^{33}$ Despite his national teleology, Topelius' vision of Finland was tolerant: he included among Finns all who lived there, including ethnic and religious minorities. He was convinced of the blessing of Russian rule but he also relativized the status of the Autocrat by writing: "In the [worldly] government are represented all classes from the Emperor to the humble rural worker [...] And all these are ruled, nearest to God, by the law of Finland." ${ }^{4}$ The book was compulsory reading for all school children up until the 1950s, and it was the familiar master narrative of the nation, and thus to be learned by heart. It emphasized social harmony, which was based on a hierarchical order but which also acknowledged the dignity of the common people-something that was crucial for the reception of the message. A scientific parallel for Topelius' work, a six-volume book series Our Own Land, was published in 1907-11. It bore the subtitle Encyclopedia for Finnish Homes. ${ }^{35}$

\section{History as Living Politics}

By the end of the nineteenth century, the history of Finland had been (re) written and the Finns widely believed that they now had a history of their own as a nation. Consequently, current events were seen in that historical framework: people and their actions were judged according to what degree they were beneficial to the cause of the nation. ${ }^{36}$ Many Swedish speakers, who saw Finnish nationalism as a cultural threat to them, claimed that the idea of separate "Finnish interests" in the past was not history but political fiction. But for the majority, Fennomania was an appealing ideology which offered membership in the "Finnish nation," an ideal community that challenged the rule of the privileged-who were not the Russians but the Swedish-speaking "better people" ( bättre folk)_occupying high positions in administration, academia, and business. The history of Finland became

\footnotetext{
${ }^{33}$ Topelius (1985), 564.

${ }^{34}$ Topelius (1985), 539. The citation has been shortened.

${ }^{35}$ Petri Karonen \& Antti Räihä, eds, Kansallisten instituutioiden muotoutuminen: Suomalainen historiakuva Oma Maa-kirjasarjassa 1900-1960 (Helsinki: SKS, 2015).

${ }^{36}$ Ilona Pikkanen, "The Emergence of a Story Space: The Image of the Club War (1596-1597) in Swedish and Finnish Historiography, 1620-1860," Scandinavian Journal of History 43:4 (2018), 515-38.
} 
a political tool in the making of a civil society marked by language and class divisions. ${ }^{37}$

An additional and complicated political dimension existed in the fact that the Russian autocracy supported the Fennomans in order to diminish the influence of Sweden in Finland, and accordingly advertised what was claimed to be the "traditional" loyalty between the Emperor and the Finnish people. The policy worked well, and the loyal Fennomansincluding Snellman and Koskinen-became the leading political force in Finland in the latter half of the nineteenth century. In that political project, the history of Finland was the unremovable bedrock of national identity - a symbol favored by Topelius. In practice that meant "awakening" the nation by writing history books, academic and popular, scientific and fictional, and founding schools and civic organizations. The project was crowned with success. By the end of the nineteenth century, a strong civil society existed in Finland, along with a rather uniform history culture that was actively nourished in education, in politics, and in the arts. ${ }^{38}$ The "national sentiments" that were manifested in music, visual arts, poetry, architecture, and so on are an example of rich imagination in inventing traditions. ${ }^{39}$ Now the object of the Fennoman elite's romance with the people was pictured as the Finnish Maid. A blond-haired girl in a colorful "national dress" became the most popular symbol and model of the nation by representing youth and purity. When the imperial family visited Finland, as they often did, they were welcomed by young women dressed up as the Finnish Maids. ${ }^{40}$

Besides the overall Lutheran worldview and rhetoric, nationalism was the most often applied argument in three political battles of the early twentieth century, those for national autonomy (political rights), cultural

\footnotetext{
${ }^{37}$ Katja-Maria Miettunen, "Yrjö Koskisen ja Magnus Gottfried Schybergsonin historiateokset ja kielikiistan pitkä varjo," in Usko, tiede ja historiankirjoitus: Suomalaisia maailmankuvia keskiajalta 1900-luvulle, ed. by Irma Sulkunen, Marjaana Niemi \& Sari Katajala-Peltomaa (Helsinki: SKS, 2016), 361-96. About the language dispute and its political dimensions, see Max Engman, Språkfroigan: Finlandssvenskhetens uppkomst 1812-1922 (Helsinki: SKS and Atlantis, 2016).

${ }^{38}$ Henrik Stenius, "Paradoxes of the Finnish Political Culture," in Nordic Paths to Modernity, ed. by Jóhan Páll Árnason \& Björn Wittrock (New York: Berghahn, 2012).

${ }^{39}$ Eric Hobsbawm \& Terence Ranger, eds, The Invention of Tradition (Cambridge: Cambridge University Press, 1984). About the visual idea of Finland, see Riitta Konttinen, Sammon takojat: Nuoren Suomen taiteilijat ja suomalaisunden kuvat(Helsinki: Otava, 2001).

${ }^{40}$ Johanna Valenius, Undressing the Maid: Gender, Sexuality and the Body in the Construction of the Finnish Nation (Helsinki: SKS, 2004).
} 
autonomy (language rights), and individual autonomy (civil rights). All three culminated and were intertwined in the constitutional crises that occurred between Finland and the Russian empire. At the core was the question of the limits of Finland's self-rule. Using historical argumentation, Finns had developed a judicial interpretation that Finland had actually already been made a state with its own constitution in $1809 .{ }^{41}$ Hence all attempts to limit its autonomy, even by the Russian autocrat himself, were illegal and unconstitutional. Historical documents were used to support the Finnish cause..$^{42}$ In fact, historians had retrospectively created a public memory in which Finland was a nation and a state - and Finns were convinced that history and law were on their side. Part of that perception was linked to the Finnish Maid who now came to be depicted as a virgin in danger, thus symbolizing the threatened nation. ${ }^{43}$ The common understanding of legality predetermined and intensified the reactions to what then happened in the years of "Russification," a period of Russian policies experienced as an assault on Finnish autonomy. The term "Russification" was widely used in Finland, although it is not quite accurate: no ethnic nor cultural oppression was introduced, and political rights were actually expanded in that period. The experiences from 1899 to 1919, from the constitutional crises to Finnish independence in 1917 and to the consequent Civil War in 1918, were to become the hard core of the national memory and of the nation's autobiography for the whole of the twentieth century.

In 1899 half a million Finns signed the Great Petition in which they asked the Emperor to withdraw the plan to implement all-imperial legislation because it violated the Finnish constitution. As Nicholas II did not understand the Petition's point and refused even to meet the delegation, which represented all Finnish localities, he was nick-named "Oathbreaker" and lost his authority as "Our Emperor." 44 The historic connection of trust that had existed between the Finnish people and their ruler was

${ }^{41}$ Leo Mechelin, Précis du droit public du Grand Duché de Finlande (Helsinki: J. C. Frenckell \& Fils, 1886) was the internationally best known argument for Finland's unique position.

${ }^{42} \mathrm{On}$ the long-time debate and its judicial and political arguments see Osmo Jussila, Suomen suurirubtinaskunta 1809-1917 (Helsinki: WSOY, 2004).

${ }^{43}$ Valenius (2004) reads it that Finnish male intellectuals saw the Finnish nation as their female beloved, a potential bride, who remained an eternal virgin menaced by the Russians. That was not the original connotation but a position that was developed in the beginning of the twentieth century.

${ }^{44}$ Päiviö Tommila, Suuri adressi (Helsinki: WSOY, 1999). 
broken in a week. The conflict intensified Russia's plans to keep Finland under control. But political tensions exploded in 1904 when the Russian Governor-General was shot to death in Helsinki. The assassin, who had committed suicide, was openly celebrated as a national hero-and for the first time aggressive nationalism, the so-called Activist Movement, gained ground in Finland. ${ }^{45}$ But further violent conflicts were avoided thanks to the leading Fennomans' prudence and the First Russian Revolution of 1905, which in Finland was followed by a week-long "National Strike" in early November. That week was experienced as a historic turning point which united the whole nation in its destiny. The demonstrations' major demand was to "restore" Finnish autonomy. That was accepted easily because the Russian government lost control of Finland for a moment. But the mass movement soon turned its attention to demanding equal rights for all members of the nation. In a "high national mood" the demand for universal suffrage was accepted by all parties under pressure from the labor movement. ${ }^{46}$

The National Strike-or the Great Strike as it was also called-was the first big political mobilization in Finland comparable to those "revolutions" abroad that Finns had been reading about. In fact, there are a lot of reports and personal impressions of the huge emotional impact of the strike week. ${ }^{47}$ It was understood and lived through as a revolution, imitating the original French example of 1789; the National Guard and the Committee of Public Safety were founded, people marched with flags and torches singing La Marsellaise and Luther's Ein feste Burg ist unser Gott. The speakers imitated the rhetoric of historical orators and the Bible, of course. One example of living a history is a description of a mass meeting in the city of Tampere when the crowds accepted the Red Manifesto, which actually was a declaration of revolution and made people feel that they were witnessing a turning point in world history:

${ }^{45}$ Tuomo Polvinen, Valtakunta ja rajamaa: N. I. Bobrikov Suomen kenraalikuvernöörinä 1898-1904 (Helsinki: WSOY, 1984) is a study of Russia's interests in Finland.

${ }^{46}$ An overview is Antti Kujala, "Finland in 1905: The Political and Social History of the Revolution," in The Russian Revolution of 1905: Centenary Perspectives, ed. by Jonathan D. Smele \& Anthony Heywood (London: Routledge, 2005), 79-93. A detailed study on the political process is Antti Kujala, Vastakkainasettelun synty: Syksyn 1905 suurlakko Helsingissä ja mumalla Suomessa (Helsinki: THPTS, 2016).

${ }^{47} \mathrm{~A}$ broad collection of various and conflicting experiences of the strike is Pertti Haapala, Olli Löytty, Kukku Melkas \& Marko Tikka, eds, Kansa kaikkivaltias: Suurlakko Suomessa 1905 (Helsinki: Teos, 1905). 
At noon, the last rumbling machines went silent. A holy strike descended over the city. Oh, wonderful days! [...] It was as if the old reality had petrified and a miraculous new one had blossomed in its place. Tens of thousands of hands had retreated from their own small chores to carry out major tasks of the government and society [...] The people played the king, enjoying the charm of the revolution while forgetting the danger of the revolution. Now the oppressive powers had fallen, just as had the Walls of Jericho. The hymns of the poor echoed up to the heavens and the poets praised the Almighty People. And so, it was heard $[\ldots]$ the Declaration for the Finnish people [...]. ${ }^{48}$

The manifesto spoke in the name of the people (the nation) and stated that "herein is said all that is - consciously or unconsciously - in the heart of every citizen who loves real freedom and human rights." It became usual to say that since that historic week there were no more subjects in Finland, only equal citizens. That was no doubt that the immediate experience, and the events of 1905, resulted in a huge increase in all kinds of political mobilization and civic activities. The importance of that historical moment was further crystallized when the following year Finland acquired the most democratic parliament in the world and the lower classes-and women-entered politics. The National Strike was commemorated as a milestone in achieving national sovereignty and democracy, "people's power" as it was then called. The strike was a concrete, lived-through moment in the birth of the nation, something which could now be dated, remembered, told, and relived more truly than the abstract idea of a nation. $^{49}$

${ }^{48}$ Väinö Voionmaa, Tampereen historia III: Itämaisesta sodasta suurlakon aikoibin (Tampere: Tampereen kaupunki, 1932 [1907]), 397-402, 412, cited 399 \& 402. The chapter was written by historian Väinö Wallin (Voionmaa) who participated in the strike and compiled the story by using his own experiences and texts and speeches from those days. The declaration became known as the Red Manifesto because some of the copies were printed on red paper after the printing house ran out of white paper. Later the color was connected to the radical message of the declaration.

${ }^{49}$ In the centennial celebrations of the strike in 2005 organized by the government and the labor movement it was not seen as correct to present critical comments which could reduce the glory of 1905 as a national achievement. 


\section{Nation Divided}

The promised national unity collapsed soon, although its story survived. Already in late-1905, one of the main organizers of the National Strike, social democrat Yrjö Mäkelin, declared: "They [workers] are now ready for class struggle because you, dear gentlemen, have isolated them to a class." ${ }^{50}$ The reason for that conclusion was, as Mäkelin claimed, that the bourgeoisie wanted to protect their class interests rather than build a true national community. Another "class division" was created by the fact that there was no longer a shared national history to believe in. Instead, there were more and more claims that "the cause of the people" (equaling the nation) had been betrayed. Workers began to distance themselves from "master class nationalism" while bourgeois intellectuals were disappointed with the people. One textile worker criticized how school children "were made to believe that some kind of Providence commands the fate of nations - instead of the peoples themselves." ${ }^{51}$ The strong social democratic party educated its members in debating and challenging bourgeois views of history and society. ${ }^{52}$ On the other side, a number of new books no longer saw the lower classes as idealized members of an ideal nation but as "mob" and as degenerate and morally weak individuals who endangered the nation's vitality. This rapid change among the leading intellectuals has been called "disillusionment with the people" which resulted from workers' defiant behavior in 1905 and from the (expected) demoralizing impact of materialism, capitalism, and urban life on the lower classes. ${ }^{53}$ The translation of social psychologist Gustave Le Bon's famous book on the irrationality of the masses signals how Finland followed the

\footnotetext{
${ }^{50}$ Yrjö Mäkelin, "Punainen julistus, työväki ja perustuslailliset," Kansan Lehti 11 November 1905.

${ }^{51}$ Tehtaalainen 23 April 1910 (a hand-written workers' paper at Finlayson Cotton Mill, Tampere). The citation has been modified.

${ }^{52}$ Jari Ehrnrooth, Sanan vallassa, vihan voimalla: Sosialistiset vallankumousopit ja niiden vaikutus Suomen työväenliikkeessä 1905-1914 (Helsinki: SHS, 1992). His main thesis is that labor movement employed lower classes' "archaic hatred" for developing emotional class struggle against the privileged (571-80).

${ }^{53}$ Risto Alapuro, Suomen älymystö Venäjän varjossa (Helsinki: Tammi, 1997), 142-50; Kukku Melkas, Heidi Grönstrand, Kati Launis, Maarit Leskelä-Kärki, Jussi Ojajärvi \& Lea Rojola, Läpikulkuibmisiä: Muotoiluja kansallisuudesta ja sivistyksestä 1900-luvun alun Suomessa (Helsinki: SKS, 2009).
} 
all-European pattern of social and political segregation-including in historiography. ${ }^{54}$

Hence, the next revolution, that of 1917 , was not encountered as a joint effort. The fall of the Emperor in March 1917 went rather smoothly in Finland and a coalition government was formed to prepare for Finland's independence. But what happened then could not have been predicted by anyone. The political distrust in 1917 led to a power struggle as to who would rule and determine the future of the coming nation state. ${ }^{55}$ Historical imagination was no longer employed to protect national unity but to guarantee its opposite, to reveal the treacherous "true" nature of one's political adversaries. The Left was repeatedly accused of betraying the nation when demanding power and cooperating with the Russian revolutionaries. For many socialists the wish of belonging to the nation was replaced by the international idea of socialism as a new kind of democratic state. The social democratic party intellectuals were convinced that revolution also represented the inevitable course of history-and was immediately at hand. For a moment, in March and November of 1917, there was some enthusiasm about the coming World Revolution-devoid of any idea of what that might entail in practice. ${ }^{56}$ The socialists who declared the "Finnish Workers' Revolution" in late January 1918 designed a nation state "ruled by the people." The planned ultra-democratic constitution was never introduced. Instead, the coup resulted in the Civil War of three months and over 37,000 deaths-most of them members of the defeated Red Guards. ${ }^{57}$

What happened surprised and shocked everyone and required an explanation. The victorious White side introduced the whole nationalistic historical repertoire to convince the public that their victory was that of the rule of law, the will of God, and the purpose of history. The Imperial

\footnotetext{
${ }^{54}$ Gustave Le Bon, Joukkosielu (Helsinki: Otava, 1912), original in French in 1895, in English The Crowd in 1896.

${ }^{55}$ On the logic of the power struggles, see Pertti Haapala, "For People's Power: Revolutions in Finland (1899-1932)," in Global Revolutions, ed. by Stefan Berger \& al (Palgrave, forthcoming 2021).

${ }^{56}$ Ehrnrooth (1992); Risto Turunen \& Sami Suodenjoki, eds, Työpäki kumouksessa (Helsinki: THPTS, 2017); Juha Siltala, "Being absorbed into an Unintended War," in The Finnish Civil War 1918: History, Memory, Legacy, ed. by Tuomas Tepora \& Aapo Roselius (Leiden: Brill, 2014), 51-89.

${ }^{57}$ On the course of the Civil War, see Tepora \& Roselius (2014) and its interpretation as a revolution, see Risto Alapuro, State and Revolution in Finland (Berkeley: University of California Press, 1988) and Haapala (2021).
} 
German army and Martin Luther were especially credited with helping the nation. ${ }^{58}$ Russophobia, which had not been that aggressive before, reached a new level. The evil that had caused the conflict and lured Finnish workers to take up arms was the "Old Archenemy" in the east, now embodied by the Bolsheviks and their Finnish accomplices. "Freedom" or "the Liberation War" (against Russia) became the official name of the Civil War used by the government, the media, and by historians. The long narrative regarding the birth and emergence of the Finnish nation-starting in prehistoric times-was reconstructed from a new perspective, one in which independence was the goal of history, a goal now reached. ${ }^{59}$ That view was an immediate response to recent experiences and also helped to accept things that should not have happened: fraternal bloodshed and violent reprisals.

In the coming years, the new "sovereign nation" was written into a history that was even more nationalistic than the idealistic version of the nineteenth century. In the White narrative, the earlier integrative elements of nationalism were replaced by an exclusive approach: the idealized Finnish population was now divided into those who had sacrificed themselves for the cause of the nation in 1918, and into those who betrayed the nation and were thus excluded from it. The history of the previous centuries was streamlined as well. The long-term Swedish impact was further neglected, while the whole Russian period of 1809-1917 was seen solely in the light of the legal and language struggles; the actual administrational and economic progress during the Russian period played no role. Typically, a new monumental popular history of Finland, A Chronicle of the Finnish People, picked out those events and persons which highlighted "Finnishness" during the course of history. Even the Kingdom of Sweden was replaced by the new concept of Sweden-Finland, which was anachronistically used to designate the time when Finland was an integral part of the Swedish kingdom. ${ }^{60}$ Finland was presented as a state-like actor between Sweden and Russia, something she never had been. The history of Finland, if not all historiography, was "Finnished" and it became the "memory of

\footnotetext{
${ }^{58}$ Government declaration on 25 May 1918 (Suomen asetuskokoelma 1918).

${ }^{59}$ Tuomas Tepora, "The Mystified War: Regeneration and Sacrifice," in Tepora \& Roselius (2014), 159-200; Aapo Roselius, "The War of Liberation, the Civil Guards, and the Veterans' Union: Public Memory in the Interwar Period," in Tepora \& Roselius (2014), 297-330.

${ }^{60}$ Einar Juva's Suomen kansan aikakirjat 1-10, was published in 1927-38 and was selectively based on Carl Grimberg's famous and popular work on Sweden.
} 
the state." ${ }^{\prime 1}$ This narrative was created by academic historians, many of whom were also visible political figures. New politically refashioned chapters were also added to Topelius' Book of Our Land.

As the history of Finland was "whitewashed," it did not work as a shared story anymore. Most people were certainly indifferent as to how the old times were described, but the new definition of our nation was found disturbing to the other half of the population, the ones who had lost the war in 1918. The Red families, and their children at school, felt it was unjust and discriminating the way in which the idea of Fatherland was monopolized by the Whites. ${ }^{62}$ On the other hand, the Left never apologized for 1918 but held on to the belief that the "revolt" had been justified. During the 1930s, the White "patriotism" was even ironized for finding its proper mental home in fascist Italy and national-socialist Germany. ${ }^{63}$ The Red experience of 1918 was encapsulated in the traditions of the labor movement, and was commemorated privately in families and publicly in labor organizations and the party press. ${ }^{64}$ Hence, the $1920 \mathrm{~s}$ and 1930s were marked by strongly divided historical experience and memory. One year, that of 1918, overshadowed all that had happened before that and negated the earlier experience of national unity, real and imagined.

Nevertheless, despite the cruelty of the Civil War, the two history cultures could live side by side, because in 1919 the White winners were compelled to come to a political compromise, one which made Finland a parliamentary democracy and allowed the defeated social democrats to return to the public arena. Gustav Schmoller's history of class struggles was now translated into Finnish as a warning as to the results of social cleavages and the failure of state authority. ${ }^{65}$ Outside politics, much of the new popular culture, especially music and films, lowered class boundaries.

${ }^{61}$ The phrase is from Henry A. Kissinger, A World Restored: Europe after Napoleon: The Politics of Conservatism in a Revolutionary Age (1964), 331-2.

${ }^{62}$ See Kaarninen's chapter in this book.

${ }^{63}$ Oula Silvennoinen, Marko Tikka \& Aapo Roselius, Suomalaiset fasistit: Mustan sarastuksen airuet (Helsinki: WSOY, 2016); Oula Silvennoinen, “'Home, Religion, Fatherland': Movements of the Radical Right in Finland," Fascism 4 (2015), 134-54.

${ }^{64}$ Tauno Saarela, "To Commemorate or Not: The Finnish Labor Movement and the Memory of the Civil War in the Interwar Period," in Tepora \& Roselius (2014), 331-63.

${ }^{65}$ Gustav Schmoller, Luokkataistelut ennen ja nyt (Helsinki: Edistyspuolue, 1920). Original title Die soziale Frage - Klassenbildung, Arbeiterfrage, Klassenkampf, published in German in 1918. 
In contrast to the nationalistic White historiography, some fiction authors were brave enough to write critically about the recent past, too, like F. E. Sillanpää, who won the Nobel Prize for literature in 1939, and Hella Wuolijoki, a popular playwright and a known socialist, who brought strong female characters to the Finnish historical scene. ${ }^{66}$ Despite political tensions and hostilities, the social democrats were much more integrated into society by the end of the 1930s than they had been two decades earlier. For example, the rapid advancement in girls' education within all social classes, and the increasing social mobility, signified the crossing of earlier class boundaries: the Finnish society had become democratic in a "deeper sense", that is, "providing equal opportunities to people from all social strata." $" 67$

When the Soviet Union attacked Finland in late-1939-with Hitler's permission-it naturally came as a shock to the Finnish society. Yet, to the astonishment of the White bourgeoisie, the vast majority of Finnish workers and socialists were willing to defend their homeland. This regained experience of unity, resembling the early forms of idealistic nationalism, came to be called the "Miracle of the Winter War," a historic moment in overcoming the trauma of the Civil War. For past decades, nationalistic propaganda had focused on the existential threat from the east, and now the ongoing war was easily positioned within the historical framework of Finland's "eternal" fight for freedom. A new chapter on the Winter War ("One Hundred Days of Honor") was further added to Topelius' Book of Our Land.

Another historically interpreted moment took place when Finland joined the German offensive against the Soviet Union in June $1941 .{ }^{68}$ For a short time, as the Germans approached Moscow and Leningrad and the Finns themselves occupied large parts of so-called East Karelia, the collapse of the Soviet Union and the coming of Greater Finland were considered realistic, even probable scenarios. Finland was described as a participant in these "world historic" events, and Finnish historians were invited to provide historical justification for the nation's expansion to the

\footnotetext{
${ }^{66}$ Panu Rajala, F.E. Sillanpää: Nobel-kirjailijan elämä 1888-1964 (Helsinki: SKS, 2015), 90-120; Anu Koivunen, Performative Histories, Foundational Fictions: Gender and Sexuality in Niskavuori Films (Helsinki: SKS, 2003).

${ }^{67}$ Heikki Waris, Suomalaisen yhteiskunnan rakenne (Helsinki: Otava, 1948), 331. His work on social divisions was a strong apotheosis of the unification of the nation.

${ }^{68}$ An overview of the impact of WWII in Finland is Tiina Kinnunen and Ville Kivimäki, eds, Finland in World War II: History, Memory, Interpretations (Leiden: Brill, 2012).
} 
east. ${ }^{69}$ As was also the case elsewhere, wartime Finland was full of patriotic and nationalistic rhetoric and symbols of sacrifice. But as it became apparent in 1942-44 that Germany would not win the war, the public rhetoric became more cautious, focusing on survival instead of on any final victory. The idea of Greater Finland experienced bankruptcy while Finns rehabilitated their Nordic identity and approached Scandinavia and the AngloAmerican world.

\section{National Reconstruction}

When Finland lost the war, and large areas of the country were ceded to the Soviet Union, the defeat was largely experienced as historical injustice. But because the country remained unoccupied, it was also seen as a war of heroic survival, thanks to the sacrifices of the whole nation, including especially the soldiers and women who had served at the front and came from all social classes and political backgrounds. There is no doubt that the war period was experienced as a joint national effort of historical significance, which leveled the divisions created in $1918 .^{70}$

Yet the defeat also challenged Finns to revise the national narrative in order to align it with the new political realities, and especially with the turn towards a friendly relationship with the Soviet Union. But academic historians, who had all kept their prewar positions, were reluctant to make any considerable revisions, although some compulsory "corrections" were made under political pressure. For example, the ultra-nationalistic and Russophobic accounts of history were forgotten. ${ }^{71}$ It has been claimed that the Soviet pressure urged Finns to "falsify" their history and to adopt a fake Soviet-friendly identity later labeled "Finlandization." If some politicians wanted to please the Soviets for political gains, academic historians in the 1950s and 1960s certainly did not. History books were not rewritten, and the overall image of Finland's history remained nationally

\footnotetext{
${ }^{69}$ Best known accounts were Väinö Auer \& Eino Jutikkala, Finnlands Lebensraum: Das geographische und geschichtliche Finnland (Berlin: Alfred Metzner Verlag, 1941); Jalmari Jaakkola, Die Ostfrage Finnlands (Berlin: Alfred Metzner Verlag, 1942). Both works were written in Finland but published and edited in Germany and added with some citations from Hitler.

${ }^{70}$ Tiina Kinnunen \& Markku Jokisipilä, "Shifting Images of 'Our Wars': Finnish Memory Culture of World War II," in Kinnunen \& Kivimäki (2012), 435-82.

${ }^{71}$ Pekka Ahtiainen, Jukka Tervonen \& Ilkka Herlin, Menneisyyden tutkijat ja metodien vartijat (Helsinki: Suomen Historiallinen Seura, 1996), 84-130.
} 
orientated, if not outright nationalistic. The emphasis was now on the historically framed national achievements like the Finnish people's "immemorial" aspiration for democracy and freedom. ${ }^{72}$ Transnational dimensions, especially the impact of Sweden and Russia on Finnish history, were further disregarded, though Finland was now often presented as a "Nordic society" distinct from Eastern Europe, which had fallen under communist rule. ${ }^{73}$ The image of the nation's history altered only gradually and mostly invisibly. The old narrative of the nation's uniqueness was preserved but linked connotations changed when Finnishness began to mean "western" and "modern" instead of remote and archaic.

If historians reacted slowly, social scientists, politicians, and novelists responded more readily to the new situation. Their idea was that the postwar reconstruction of the nation required a new identity based on social and political integration, modernization of the economy, and political neutrality. The new concepts applied in defining Finnish society were modernity and the Nordic Model, which gradually came to define the country's national identity and history: Finland was presented as a small and homogeneous Nordic nation with deep roots in Lutheran Christianity, democracy, and equality, and which materialized in the tradition of a free peasantry and the early introduction of women's rights. Finnish culture was unique in that it had rapidly developed from peripheral and poor conditions into one of the most advanced in the civilized world. In public discourses Finns were now told to believe that their history, which was traditionally filled with wars, poverty, and foreign rule, was actually a "story of survival" and finally of "success," as witnessed by economic historians. ${ }^{74}$ From the 1960 s onwards the national identity was linked to material prosperity, technological development and, above all, to education. The "vitality of the nation" was no longer seen only in population growth but in the nation's "innovation capacity." The self-portrait of

\footnotetext{
${ }^{72}$ Arvi Korhonen, "Suomalaisen kansanvallan juuret," in Suomalaisen kansanvallan kehitys, ed. by Pentti Renvall (Porvoo: WSOY, 1856), 8-14. The book includes ten chapters of the "roots of people's power" in Finland, that is, the true idea and content of the nation.

${ }^{73}$ Petteri Norring, "The Rhythm and Implicit Canon of Nordic History by Eli F. Heckscher and Eino Jutikkala," in Making Nordic Historiography: Connections, Tensions and Methodology 1850-1970, ed. by Pertti Haapala, Marja Jalava \& Simon Larsson (New York: Berghahn Books, 2017), 207-34.

${ }^{74}$ Jari Ojala, Jari Eloranta \& Jukka Jalava, eds, The Road to Prosperity: An Economic History of Finland (Helsinki: SKS, 2006).
} 
modern Finnish society was reflected via the highly appreciated modern architecture and design. ${ }^{75}$

Even though the reconstruction of the economy, the resettlement of evacuees, and the building of new homes for a growing population kept people busy in the postwar period, the war experience could not be glossed over that easily. In the immediate postwar decades, professional historians did not touch the troublesome topics of $1939-45$, just as they did not delve into the tragedy of 1918 but remained silent or held on to their "objectivity." 76 Hence, the task of treating the traumatic experiences of war was left to novelists and film makers. Among the hundreds of book titles of war fiction, one novel became an unparalleled bestseller and was read and approved of by the majority of Finns - with the exception of the conservative elites.

Väinö Linna's Unknown Soldiers (1954) was a realistic, lively, and ironic story of the war in 1941-44 as experienced by the author himself and his fellow soldiers who were not supposed to be war heroes. The novel was inspired by Erich Maria Remarque's classic All Quiet on the Western Front (1929) and shared many of its qualities. In addition to micro-historical realism, the story challenged the patriotic and nationalistic rhetoric. And yet, in the end, Linna's stubborn and misbehaving frontline soldiers saved the country. The novel's true heroes were the common people, often the sons of the despised Reds of 1918. Thus, Linna stole the glory from those conservative circles that had upheld the heritage of White Finland and appropriated the patriotic values to themselves. Even more importantly, his novel and its wide publicity helped ordinary people, and especially the rank-and-file soldiers, to relocate themselves within a historically plausible war narrative of their own. The novel was filmed immediately in 1955 and is still shown on national television on every Independence Day. Several later novels, films, plays, and studies have not essentially changed the image Linna created but, rather, confirmed the narrative. ${ }^{77}$ That is how

\footnotetext{
${ }^{75}$ About the twentieth-century societal optimism, see Pertti Haapala, "2017: Finlands framtids historia," in Öppet fall: Finlands historia som möjligheter och alternativ, ed. by Petri Karonen \& Nils-Erik Villstrand (Helsinki: SLS, 2017); Juhani Koponen \& Sakari Saaritsa, eds, Nälkämaasta hyvivointivaltioksi: Suomi kehityksen kiinniottajana (Helsinki: Gaudeamus 2019).

${ }^{76}$ Ahtiainen \& Tervonen (1996). The first balanced study on 1918 was published in 1957 - and was rejected by history professors.

${ }^{77}$ Väinö Linna, Tuntematon sotilas (Helsinki: WSOY, 2000 [1954]). The latest translation in English: Unknown Soldiers, trans. by Liesl Yamaguchi (London: Penguin Books, 2015).
} 
fiction became publicly accepted history and people relived their past through it-even mixing fiction and their own experiences. In the final lines of his novel, Linna reformulated the politically ambivalent outcome of the war as a joke: "The USSR won, but small and brave Finland came in a good second." $" 78$

Linna's next book was a trilogy, Under the North Star (1959-61), which expanded his historical revision to the high period of nation-making which extended from the 1870 s to the $1950 \mathrm{~s} .{ }^{79}$ It is a saga of a crofter family and a fictitious history of the background and consequences of the Civil War in a rural locality. The novel has been read as the "true history" of the Red experience, and, as a reflection of many Finnish family histories, the story has preserved its appeal and relevance till today. ${ }^{80}$ But when the book was first published, it was a radically new way of presenting this history: there was not yet at the time any balanced research on 1918, so the White narrative dominated the public discourse, and the traumatic experiences of illegal executions and starvation in prison camps were practically silenced. As with The Unknown Soldiers, the novel was welcomed with enthusiasm, but it was also criticized: Linna was accused of falsifying history, insulting the nation and, furthermore, of being a poor and old-fashioned writer. Linna was especially surprised and hurt by the critique from professional historians who were clearly annoyed when an amateur entered their territory. In the public debate that followed, Linna was triumphant. To the claims about his historical ignorance he responded: if you sell nearly million copies you can't be that wrong. ${ }^{81}$

The self-educated author, a factory worker from Tampere, did not aim to be a history writer but Linna acquired this role in public and he defended his views like any historian. He accused the academics of "hiding the truth from the people" and challenged national historiography by calling it "national ideology." As an author, he called his own method

On Linna's impact, see Jyrki Nummi, Maria Laakso, Toni Lahtinen \& Pertti Haapala, eds, Väinö Linna: Tunnettu ja tuntematon (Helsinki: WSOY, 2020).

${ }^{78}$ Linna (2000 [1954]), 477.

${ }^{79}$ Väinö Linna, Täällä Pohjantähden alla 1-3 (Helsinki: WSOY, 2000 [1959-1962]). Translation in English: Under the North Star 1-3, trans. by Richard Impola (Beaverton: Aspasia Books, 2001-03).

${ }^{80}$ Nummi \& al (2020).

${ }^{81}$ Väinö Linna, Esseitä (Helsinki: WSOY, 2000), 176-83. 
"sociology." 82 According to him, the national narrative did not see people as actors with their own motives but as passive statists of history who were used to glorify the national elite's patriotic intentions. He accused the Finnish intelligentsia of self-delusion and, referring to the Civil War, noted sarcastically: "The holy image of the Finnish people was now broken and that caused such hatred that they tried to fix the picture by killing the model." 83 That was a barb at the followers of Runeberg and Topelius and their idealistic nineteenth-century imagination of the Finnish nation. Linna wanted to unseat the old-fashioned idea of national history with its child-like subjects and replace it with true people's history, that of rational, adult individuals. His mpact was huge on the ways people began to read and relive history as their own story. Unlike in the nineteenth-century genre, Linna's novels brought history close to people's everyday lives and experiences-many of his readers "witnessed in their own case" and hence lived their past twice.

\section{Deconstruction and Recomposition}

Although Linna became a celebrated oracle in explaining the fate of the nation, he was not the only one representing the new mainstream. The generation gap in the Finland of the 1960s was as clear as in all Western societies. Cultural critique of conservative nationalism was wide and successful; old key slogans like "Home, Religion, Fatherland" now seemed outdated. ${ }^{84}$ Yet history did not lose its importance as a key component of national identity. Thinking of the past in national terms did not disappear, but the content of the nation, its meaning, changed. In the public vocabulary nation was often replaced by society, which included the state, population, trades, classes, and so on. Society could still mean what Topelius had called the "shared community of all," but the logic was different: it was no longer a hierarchy with given positions but a complex, mobile organization of various social groups, individuals, and their actions.

\footnotetext{
${ }^{82}$ Linna (2000), passim; Pertti Haapala, "Writing Our History: The history of the 'Finnish people' (as written) by Zacharias Topelius and Väinö Linna," in Haapala, Jalava \& Larsson (2017), 25-54.

${ }^{83}$ Linna (2000), 247-8.

${ }^{84}$ Marja Tuominen, Me kaikki ollaan sotilaitten lapsia: Sukupolvihegemonian kriisi 1960luvun suomalaisessa kulttuurissa (Helsinki: Otava 1991).
} 
In the wake of social sciences, which created a new language to describe the society, historiography went through a conceptual change as well. This began with a critique of nationalistic teleology through focusing on the blind spots in the national history and introducing those people and social groups previously "forgotten" in the collective narrative. In the 1960s, a new generation of historians started to revise the critical moments in national history: those of 1809, 1905, 1917, 1918, and 1939-45. Large government-funded research projects on the Civil War made it one of the best and most openly investigated internal conflicts in the world. ${ }^{85}$ The new image of the war was much more multifaceted, fragmented, and problematic, and this made political identification with the Reds or the Whites much more complicated. The same was true for World War II: in closer scrutiny, Finns were not seen only as innocent victims in 1939-45 but had their own dark histories to study and explain. At the same time, and as a small country in a global conflict, Finland was a piece of a bigger puzzle. This metaphor carried on to the Cold War era, in which Finland was a tiny and neutral actor between the Great Powers. Consequently, Finns developed a small nation identity, which acknowledged the harsh experiences of the war years but also retained a considerable degree of national self-esteem. ${ }^{86}$

When the traditional historicist narration with descriptive stories of active individuals was replaced by more holistic and social scientific approaches with structures and numbers, historical experience lost some of its appeal for identification. Yet historical experience as a basis for identities remained (or returned) in two ways: through the popularity of personal stories, that is, biographies and memoirs, and through the new social history with its promise to "revive the narrative." That international trend arrived in Finland in the 1980s and boomed in topics like labor history, family history, women's history, oral history, and the histories of many minorities. ${ }^{87}$

${ }^{85}$ Bill Kissane, "On the shock of civil war: cultural trauma and national identity in Finland and Ireland," Nations and Nationalism 26:1 (2019), 22-43.

${ }^{86}$ Kinnunen \& Jokisipilä (2012); Seppo Hentilä, "Historiantutkijat sotien jälkeisessä yhteiskunnassa," in Tiede ja yhteiskunta: Suomen Historiallinen Seura ja historiantutkimus, ed. by Petri Karonen (Helsinki: SKS, 2019), 523-76.

${ }^{87}$ Pertti Haapala \& Pirjo Markkola, "Se toinen (ja toisten) historia," Historiallinen Aikakauskirja 115:4 (2017), 403-16. 
As Finland was a rather homogenous society, the new social history did not see its task as much in eliminating national history as in rebuilding it. Forgotten and ignored individuals and social groups were added to the national narrative and their role as "nation-builders" was underlined. The relevance of women's history, for example, was justified by studying the making of the nation and civil society in the nineteenth and early twentieth century and by showing women's essential role in this process. ${ }^{88}$ Similarly, the working class and the peasants were integrated into national history as active participants in nation-making. Furthermore, histories of education, media, and popular culture added to the story of how the nation was made in people's minds and in their everyday life. That is how researchers found a new kind of history and offered it to their readers as a participatory perspective on one's own past: "Dig where you stand." In a way, national history was democratized and "given back to the people," and it was now experienced more often through novels, films, TV-series, documentaries, and exhibitions than through academic historiography. Compared to other Western countries, Finland was no exception in this, but it is worth noting that in the Finnish case the new ways of representing "living history" did not actually challenge the national framework used in seeing the past, but just expanded it.

Postmodernist conceptualizations entered Finnish historiography at the turn of the new century. Younger historians began to problematize the premises of national history and see it as a politically motivated narrative construction, one among other grand narratives. ${ }^{89}$ Instead of being an axiomatic paradigm, national history - as well as nationalism-became a subject of study and was seen through people's experiences, that is, how they had lived their lives as members of a nation. When transnational and global history began to boom from the 1990s onwards, historians started to emphasize the cross-border connections and intertwinements. The whole idea of Finland as a historical entity was challenged and the History of Finland was seen more and more as an identity project. ${ }^{90}$

\footnotetext{
${ }^{88}$ As an example, see Merja Manninen \& Päivi Setälä, eds, The Lady With the Bow: The Story of Finnish Women (Helsinki: Otava, 1991).

${ }^{89}$ Kenneth Partti, Taking the Language of the Past Seriously: The Linguistic Turns in Finnish and Swedish History Dissertations, 1970-2010 (Jyväskylä: University of Jyväskylä, 2020).

${ }^{90}$ See the theme issue on national history, Historiallinen Aikakauskirja 115:4 (2017); Karonen \& Villstrand (2017).
} 
The revision of national history in the latter half of the twentieth century had its political dimensions, too. First, it supported the integrative public policies that aimed at national consensus in foreign and domestic politics and at the modernization of the country, socially and economically. The making of the Finnish welfare state from the 1960s onwards became a new national effort and an identity marker which was also reflected in historiography. For a small country, history has been used to emphasize national survival and economic success. This publicly cherished storyline has been nurtured by the various international listings in which Finland has been named the best educated, the most equal, the healthiest, the wealthiest, or the happiest nation on earth. Since globalization has been experienced as a positive change for most Finns, it has also been included in the national success story of a small but clever society navigating the international markets and exploiting new opportunities. In the beginning of the twenty-first century, the government declared that globalization (and global problems) should be faced as "one nation," which can be seen as a return to old rhetoric and the identity of a "joint Finnish nation." ${ }^{91}$ However, as a crucial difference, there was no longer any explicitly ideological commitment to the idea of nationalism, but rather a practical interest in creating social cohesion and international "competitiveness" in a diverse society that includes minorities and immigrants. In terms of historical identity this means that the nation, a true social and political community, has reshaped its premises but has also partly retained (or revived) some old thinking patterns regarding the national narrative, albeit in a new form.

\section{Conclusion}

As elsewhere in Europe, national historiography in Finland was originally a project of the political and academic elites, who wanted to develop a narrative of the common past to be adopted by all. The story turned out to be a success and became a model for the common people's historical experience, despite the fact that the narrative's reception has always been divided, indifferent, and complex. The response was not an issue of historical or scientific "truth" but of how convincing the story could be for

\footnotetext{
${ }^{91}$ Pauli Kettunen, Globalisaatio ja kansallinen me: Kansallinen katseen historiallinen kritiikki (Tampere: Vastapaino 2008).
} 
people to make sense of their lives and of the nation as a greater context for their personal experiences. The story's attraction was largely based on easily identifiable narrative elements, like family metaphors and Biblical content, and, above all, on the political hopes of promoting collective identity and participating in the state-making. This is how a narrative of the past became social reality, the autobiography of a nation and a society, as well as a crucial element for social cohesion, political order, and cultural identity.

While the nineteenth century saw the rise of national history, the twentieth century witnessed its final success in the state formation and the consequent Finnish identities, which were bound to key turning points in the nation's history. As the twenty-first century began with high hopes of globalization, it seemed like national history among other grand narratives would lose its relevance. Yet in fact, globalization was turned into a "national challenge." It is surprising how widely globalization has been seen through national lenses and truly transnational global history remains a challenge for scholars everywhere..$^{2}$

The Finnish historiography of the past 200 years can thus be seen as a "success story" of methodological nationalism, that is, how the nation was made the object, the subject, and the scope of history, even when the limitations and excesses of national history were simultaneously criticized..$^{93}$ To understand that development it is good to remind that national history has been, above all, a social practice and ideology in creating national community and its respective identities. The experience of Finland as a living nation demonstrates that historiography really matters. Historians and philosophers invented the whole thing, the idea of national history, and believed that they could see the nations' future, too. In that sense they were not writing in any academic ivory towers but playing a visible role in society and its development. It is difficult to determine exactly how deep and sustained their impact has been-but it is even more difficult to see how things would have gone without their ideas and contribution.

\footnotetext{
${ }^{92}$ Lynn Hunt, Writing History in the Global Era (New York: Norton, 2014).

${ }^{93}$ Daniel Chernilo, "The critique of methodological nationalism: Theory and history," Thesis Eleven 106:1 (2011), 98-117.
} 
Open Access This chapter is licensed under the terms of the Creative Commons Attribution 4.0 International License (http://creativecommons.org/licenses/ by $/ 4.0 /$ ), which permits use, sharing, adaptation, distribution and reproduction in any medium or format, as long as you give appropriate credit to the original author(s) and the source, provide a link to the Creative Commons licence and indicate if changes were made.

The images or other third party material in this chapter are included in the chapter's Creative Commons licence, unless indicated otherwise in a credit line to the material. If material is not included in the chapter's Creative Commons licence and your intended use is not permitted by statutory regulation or exceeds the permitted use, you will need to obtain permission directly from the copyright holder.

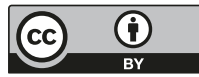

